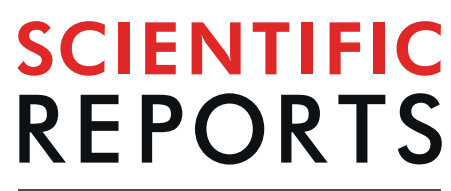

natureresearch

Check for updates

\title{
Tracking the Near Eastern origins and European dispersal of the western house mouse
}

\author{
Thomas Cucchi ${ }^{1 凶}$, Katerina Papayianni ${ }^{1,2}$, Sophie Cersoy ${ }^{3}$, Laetitia Aznar-Cormano ${ }^{4}$, \\ Antoine Zazzo ${ }^{1}$, Régis Debruyne ${ }^{5}$, Rémi Berthon ${ }^{1}$, Adrian Bălășescu ${ }^{6}$, Alan Simmons ${ }^{7}$, \\ François Valla ${ }^{8}$, Yannis Hamilakis ${ }^{9}$, Fanis Mavridis ${ }^{10}$, Marjan Mashkour ${ }^{1}$, Jamshid Darvish ${ }^{11,24}$, \\ Roohollah Siahsarvi ${ }^{11}$, Fereidoun Biglari ${ }^{12}$, Cameron A. Petrie ${ }^{13}$, Lloyd Weeks ${ }^{14}$, \\ Alireza Sardari ${ }^{15}$, Sepideh Maziar ${ }^{16}$, Christiane Denys ${ }^{17}$, David Orton ${ }^{18}$, Emma Jenkins ${ }^{19}$, \\ Melinda Zeder ${ }^{20}$, Jeremy B. Searle ${ }^{21}$, Greger Larson ${ }^{22}$, François Bonhomme ${ }^{23}$, \\ Jean-Christophe Auffray ${ }^{23}$ \& Jean-Denis Vigne ${ }^{1}$
}

The house mouse (Mus musculus) represents the extreme of globalization of invasive mammals. However, the timing and basis of its origin and early phases of dispersal remain poorly documented. To track its synanthropisation and subsequent invasive spread during the develoment of complex human societies, we analyzed 829 Mus specimens from 43 archaeological contexts in Southwestern Asia and Southeastern Europe, between 40,000 and 3,000 cal. BP, combining geometric morphometrics numerical taxonomy, ancient mitochondrial DNA and direct radiocarbon dating. We found that large late hunter-gatherer sedentary settlements in the Levant, c. $14,500 \mathrm{cal}$. BP, promoted the commensal behaviour of the house mouse, which probably led the commensal pathway to cat domestication. House mouse invasive spread was then fostered through the emergence of agriculture throughout the Near East 12,000 years ago. Stowaway transport of house mice to Cyprus can be inferred as early as

\footnotetext{
${ }^{1}$ Archéozoologie, Archéobotanique: Sociétés, Pratiques et Environnements (AASPE), UMR 7209, CNRS, Muséum national d'Histoire naturelle, Paris, France. ${ }^{2}$ Malcolm H. Wiener Laboratory for Archaeological Science, American School of Classical Studies, Souidias 54, 10676, Athens, Greece. ${ }^{3}$ Centre de Recherche sur la Conservation (CRC), Muséum national d'Histoire naturelle, CNRS, Ministère de la Culture, CP 21, 36 rue Geoffroy Saint-Hilaire, 75005, Paris, France. ${ }^{4}$ Centre de recherche en Paléontologie Paris, UMR7207, Muséum national d'Histoire naturelle, CNRS, Sorbonne Université, 8 rue Buffon, 75005, Paris, France. ${ }^{5}$ DGD-REVE, Muséum national d'Histoire naturelle, 17 Place du Trocadéro, bureau E205, 75016, Paris, France. ${ }^{6}$ Vasile Pârvan, Institute of Archaeology, Romanian Academy, 11 Henri Coandă Street, Bucarest, Romania. ${ }^{7}$ Department of Anthropology, University of Nevada, Las Vegas/Desert Research Institute, Reno, Nevada, USA. ${ }^{8}$ Archéologies et Sciences de l'Antiquité (Arscan), UMR 7041 CNRS, Université de Paris Nanterre, Paris I, 92023, Nanterre, France. ${ }^{9}$ Joukowsky Institute for Archaeology and the Ancient World, Brown University, Box 1837, 60 George Street, Providence, RI, 02912, USA. ${ }^{10}$ Ephorate of Palaeoanthropology and Speleology, Hellenic Ministry of Culture and Sports, Ardittou 34B, 11636, Athens, Greece. ${ }^{11}$ Department of Biology, Faculty of Sciences, Ferdowsi University of Mashhad, Mashhad, Iran. ${ }^{12}$ Paleolithic Department, National Museum of Iran, Tehran, Iran. ${ }^{13}$ Department of Archaeology and Anthropology, University of Cambridge, Downing Street, Cambridge, CB2 3DZ, UK. ${ }^{14}$ Archaeology, School of HASS, University of New England, Armidale, NSW, 2351, Australia. ${ }^{15}$ Research Institute of Cultural Heritage and Tourism (RICHT), Iranian Center for Archaeological Research (ICAR), Tehran, Iran. ${ }^{16}$ Near Eastern Archaeology, Institute für Archäologie Wissenschaften, Johann Wolfgang Goethe Universität, Frankfurt am Main, Germany. ${ }^{17}$ Institut de Systématique, Evolution, Biodiversité (ISYEB), UMR 7205, Muséum national d'Histoire naturelle, Sorbonne Université, Ecole Pratique des Hautes Etudes, Université des Antilles, CNRS, Paris, France. ${ }^{18}$ BioArCh, Department of Archaeology, University of York, York, YO10 5DD, UK. ${ }^{19}$ Institute for the Modelling of Socio-Environmental Transitions, Bournemouth University, Talbot Campus, Poole, BH12 5BB, UK. ${ }^{20}$ Department of Anthropology, National Museum of Natural History, Smithsonian Institution, Washington, District of Columbia, USA. ${ }^{21}$ Department of Ecology and Evolutionary Biology, Corson Hall, Cornell University, Ithaca, NY, 14853-2701, USA. ${ }^{22}$ Palaeogenomics and Bio-Archaeology Research Network, School of Archaeology, University of Oxford, Oxford, OX1 3TG, UK. ${ }^{23}$ Institut des Sciences de l'Evolution (ISEM), UMR 4554, CNRS, IRD, EPHE, Université de Montpellier, Montpellier, France. ${ }^{24}$ Jamshid Darvish is deceased. ${ }^{\bowtie}$ e-mail: cucchi@ mnhn.fr
} 
10,800 years ago. However, the house mouse invasion of Europe did not happen until the development of proto urbanism and exchange networks - 6,500 years ago in Eastern Europe and 4000 years ago in Southern Europe - which in turn may have driven the first human mediated dispersal of cats in Europe.

The impact of our species on biodiversity was initiated with the global dispersal of Homo sapiens from the Late Pleistocene $e^{1-3}$. Anthropogenic biological invasions are another key component of biodiversity loss ${ }^{4}$. Despite their natural occurrence since the beginning of life on Earth, biological invasions have drastically increased with human activities ${ }^{5}$, facilitating species dispersal ${ }^{6}$. The house mouse (Mus musculus ssp.) is emblematic of these anthropogenic biological invasions threatening biodiversity ${ }^{7,8}$. Although often overlooked compared with commensal rats (Rattus rattus, $R$. norvegicus and $R$. exulans), this elusive mammal has been a much more successful invasive rodent, becoming almost as ubiquitous as H. sapiens ${ }^{9}$. Originating in the Indo-Pakistan subcontinent and neighbouring Afghanistan and Iran ${ }^{10-12}$, house mice differentiated during the Pleistocene climatic oscillations ${ }^{9}$ into three main Mus musculus subspecies (M. m. domesticus, M. m. musculus and M. m. castaneus). All these subspecies are human commensals, facilitating their long-distance colonization and ultimately their cosmopolitan range ${ }^{13}$.

The inextricable link between human dispersal, its associated processes of niche construction and the global invasive process of the house mouse makes it a relevant bio-indicator of human impact on biodiversity, which we can track in the bioarchaeological record. Currently, bioarchaeological evidence and genetic studies on modern populations agree on the origin of $M . m$. domesticus commensal behavior associated with the Neolithic transition in the Near East ${ }^{9,14}$. But whether sedentism ${ }^{15}$ and/or the rise of the farming economy ${ }^{14,16}$ were the key driving factors that led to this behavioural shift is debated. The dispersal of $M$. m. domesticus towards Europe has been deemed to follow the Neolithic diaspora stemming from Southwest Asia; yet, current understanding of the zooarchaeological occurrences rather suggests a house mouse dispersal in Mediterranean Europe along with Iron Age demographic and commercial movements ${ }^{17}$. If this process is well documented for the western Mediterranean, it remains to be ascertained for the Eastern Mediterranean, where archaeological evidence is too scarce to discard potential earlier Neolithic or Bronze Age dispersals. Finally, the dispersal history of $M$. $m$. musculus, the other commensal house mouse in Europe, currently present in central and Northern Europe, is so far only documented in Chalcolithic Romania 6,500 years ago ${ }^{14,18}$, but its origin and the timing of its dispersal route need to be unravelled.

The commensal house mouse is considered to have initiated the commensal trajectory of the cat towards domestication ${ }^{19-22}$, implying that tracking the bioarchaeological history of the former lays the trail for the latter. Mitochondrial DNA suggests that the domestication of the African wild cat (Felis silvestris lybica) took place amidst the rise of agriculture in the Neolithic Near East ${ }^{23,24}$. The earliest and most striking evidence of cat domestication comes from 9,500 cal BP in Pre-Pottery Neolithic (PPN) Cyprus ${ }^{19,25}$. Its introduction onto the island is thought to be tied to the control of the proliferation of the house mouse populations, present on the island since the Early PPNB ${ }^{26}$. The appearance of the domestic cat in western European archaeological contexts during the Iron Age, around 3,000 years ago, is synchronous with the strong evidence for the house mouse biological invasion of western Europe ${ }^{17}$. This co-dispersal of cats and house mice has also been mentioned in literary sources, describing the deliberate transport of domestic cats on ships to control rodent pests, inducing its worldwide distribution ${ }^{24,27}$. This co-phylogeography supports the premise that understanding the house mouse's origin and dispersal can lead to insights pertaining to the origin of domestic cats and their subsequent dispersal.

To document the timing and pace of human mediated house mouse dispersal and provide new insights into the origin and dispersal of domestic cats, we collected and analysed 829 ancient mouse (Mus sp.) dental remains from 43 archaeological sites located in Southwest Asia and Europe, spanning 40,000 years from the Upper Pleistocene to the Late Bronze Age. Their numerical taxonomy was performed using geometric morphometric $(\mathrm{GMM})$ analyses of the first lower molar $(\mathrm{m} 1)$ shape as a proxy ${ }^{28}$, using Bayesian models and machine learning approaches. In addition, 85 samples for ancient mtDNA sequences (Cytochrome $b$ ) and direct radiocarbon dating were collected on the GMM identified specimens to support the taxonomic identification and provide direct dates respectively.

\section{Results}

Strategy for data acquisition. Our Mus sp. archaeological dataset includes 829 specimens from 43 sites sampled across the Middle East and Eastern Mediterranean Europe, as a core area for the origin and spread of agriculture in Europe, close to the cradle of Mus musculus ssp. lineages, along a temporal span from 40,000 cal BP to 3,000 cal BP (Fig. 1b location, Supplementary Table S1). We defined five key chronological phases of human history in the studied area: (1) the pre-sedentism period: 40,000-15,500 cal BP, (2) the early sedentary communities of hunter-gatherers: $15,500-12,000 \mathrm{cal} \mathrm{BP},(3)$ the early agrarian economy and dispersal in the Near East and Cyprus: 12,000-8,500 cal BP, (4) the Neolithic dispersal towards Europe: 8,500-6,500 cal BP, and (5) the Late Neolithic/Bronze Age exchange and trade networks: 6,500-3,000 cal BP.

Samples came from in situ deposits of $M u s$ sp. remains, excluding specimens from disturbed archaeological contexts. Some sites provided only one specimen which was kept for analysis due to the reliability of their original context (Supplementary note S2). The GMM numerical taxonomy of the archaeological specimens relies on a comparative analysis of 512 genotyped specimens (Supplementary Table S3) including the three wild species (M. macedonicus, M. spicilegus, M. cypriacus) and three commensal subspecies (M. m. domesticus, M. m. musculus and M. m. castaneus) present in the studied area. We assessed the phenotypic diversity and relationships among the modern and archaeological "populations" using Bayesian models and machine learning classification 
a

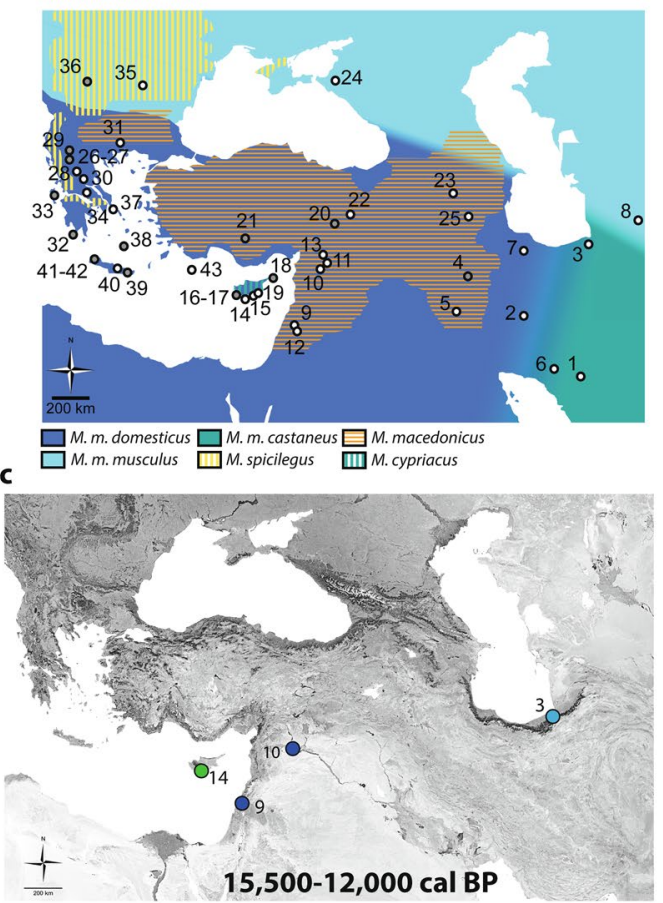

.

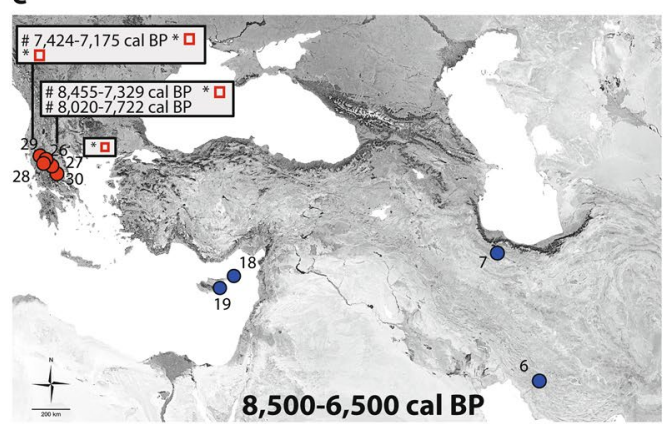

b

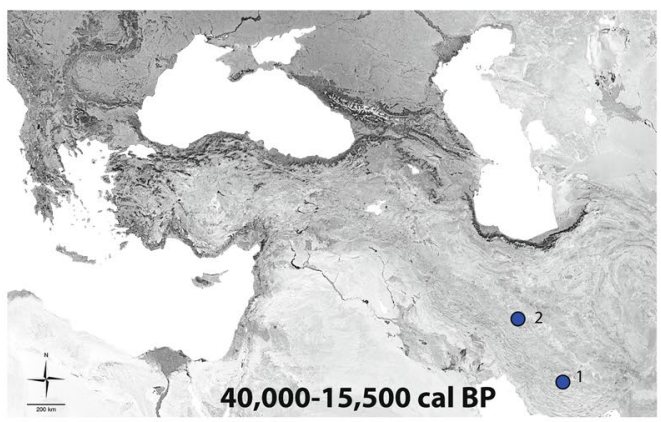

d

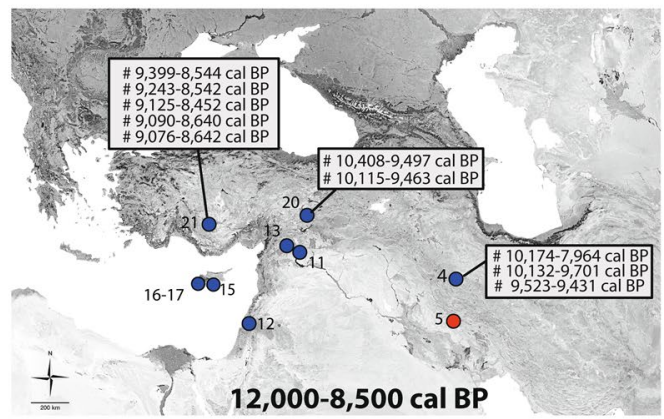

f

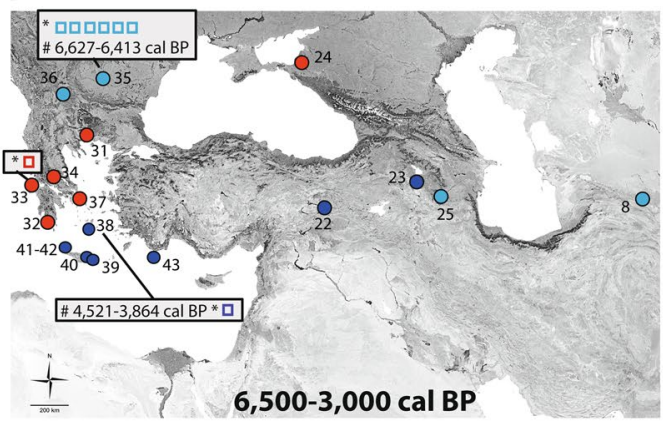

Figure 1. Spatio-temporal representation of the house mouse dispersal in Southwestern Asia and Eastern Europe. (a) Current distribution of the three commensal subspecies from the studied area: M. m. domesticus, M. m. musculus, M. m. castaneus and the three non-commensal species: M. spicilegus, M. macedonicus and M. cypriacus. Localisation of the archaeological sites studied. Circles filled in grey identify sites where aDNA and radiocarbon analyses have been performed (See the supplementary note S2 for details). 1: Qaleh Bozi, 2: Eskaft-e Gavi, 3: Ali Tappeh, 4: Ganj Dareh, 5: Ali Kosh, 6: Tol-e Nourabad, 7: Tepe Zagheh, 8: Ulug Depe, 9: 'Ain Mallaha, 10: Mureybet, 11: Jerf El Ahmar, 12: Netiv Hagdud, 13: Djadé, 14: Akrotiri-Aetokremnos, 15: Klimonas, 16: Kissonerga-Mylouthkia 1, 17: Kissonerga-Mylouthkia 2, 18: Cape Andreas-Kastros, 19: Khirokitia, 20: Cafer Höyük, 21: Çatalhöyük, 22: Norsun Tepe, 23: Ovçular Tepesi, 24: Chishko, 25: Kohne Pasgah Tepesi, 26: Mavropigi, 27: Xirolimni, 28: Theopetra, 29: Avgi, 30: Koutroulou Magoula, 31: Dikili Tash, 32: Alepotrypa, 33: Drakaina, 34: Sarakenos, 35: Bucșani La Pod, 36: Vinča-Belo Brdo, 37: Ayia Triada, 38 : Akrotiri, 39: Mochlos, 40: Malia, 41: GSE, 42: Chania, 43: Uluburun shipwreck (See supplementary Note S2 for details). (b-f) Diachronic mapping of the dispersal of the M. musculus lineages identified by numerical taxonomy performed using GMM on the first lower molar: M. $m$. domesticus (deep blue full circle), M. $m$. musculus (light blue full circle), M. spicilegus/M. macedonicus (red full circle) and M. cypriacus (green full circle). Direct radiocarbon dating at $95.4 \%$ probability (\#) and the ancient mtDNA Cytochrome $b$ taxonomic identification $\left(^{*}\right)$ are provided (See the Supplementary Table S6 and S12 for details). Each square represents a specific aDNA identification and its color corresponds to three taxonomic units: $M$. m. domesticus (deep blue square), M. m. musculus (light blue square), and M. spicilegus/M. macedonicus (red square). Map adapted from (https://d-maps.com) by D.G. Kuriyama. Figure generated by TC and KP in Adobe Illustrator CS6.

methods, in order to build a diachronic map of the emergence and dispersal of the commensal subspecies across the five chronological phases (See Methods section). 
Among the 829 specimens selected for GMM identification, only 85 were suitable for an integrated approach combining GMM, aDNA and radiocarbon dating from the same specimen. Indeed, this analytical approach necessitated complete mandibles which could be divided into three sub-samples: the $\mathrm{m} 1$ tooth for the GMM analysis and half the hemi-mandible for aDNA and radiocarbon dating. Considering the size and the weight range of half hemi-mandibles samples (from 6 to $40 \mathrm{mg}$ ), this approach proved challenging (See Methods section). Among the 85 samples selected, only 17 provided positive results for radiocarbon dating and only 15 genuine ancient sequences for the Cytochrome $b$ fragment (Supplementary Table S4).

Pre-Neolithic mice in Southwestern Asia. We identified M. m. domesticus in the Iranian Plateau from two Middle and Upper Paleolithic cave deposits in the central and southern Zagros (Fig. 1b, Supplementary Methods S5). These Mus remains from Qaleh Bozi and Eskaft-e Gavi result from non-anthropogenic deposits likely accumulated by birds of prey ${ }^{29-31}$, providing the oldest fossil evidence for the presence of non-commensal M. m. domesticus populations in the Iranian Plateau before the Neolithisation process in the Near East.

At the transition between the Pleistocene and the Holocene, we found M. m. domesticus in the earliest sedentary open-air settlements of hunter-gatherers in the Southern and the Northern Levant (Fig. 1c, Supplementary Methods S5), from the early Natufian layers of 'Ain Mallaha between 14,500 and 13,000 cal BP and from the later Natufian and Khiamian layers of Mureybet at 12,000 cal BP (Fig. 1c), respectively.

The occurrence of M. m. musculus in the Ali Tappeh cave between 15,201-14,758 and 12,080-11,615 cal BP (Fig. 1c, SI Fig. 1) provides the evidence for this subspecies in Northeastern Iran during the Late Glacial. However, we cannot relate this occurrence with an in situ commensal accumulation, since archaeological evidence does not support any sedentary occupation of the cave by human communities ${ }^{32,33}$.

In the Epipaleolithic Akrotiri-Aetokremnos rock-shelter in Cyprus (Fig. 1c, Supplementary Methods S5), from where the earliest human presence on Cyprus has been inferred ${ }^{34,35}$, we found evidence of Mus cypriacus, the extant endemic mouse of Cyprus ${ }^{36}$. This confirms its presence on the island before the human Neolithic colonization, and probably since the Middle Pleistocene, considering the phenotypic relationship of the fossil Mus remains in Cape Pyla ${ }^{37,38}$ with Mus cypriacus ${ }^{39}$.

Pre-Pottery Neolithic (PPN) range expansion in Southwestern Asia. We found M. m. domesticus populations in the early PPNA farming villages of the Northern Levant (Jerf El Ahmar) and Southern Levant (Netiv Hagdud), dated to 12,000 cal BP (Fig. 1d, Supplementary Methods S5) as well as between 11,100 and $10,600 \mathrm{cal}$ BP in the PPNA village of Klimonas, Cyprus (Fig. 1d, Supplementary Methods S5). This identification in Klimonas relies on a single molar found in a secure context within the floor deposit of the village's communal building, but its occurrence in greater numbers is supported by 41 remains of Mus sp. and gnawing marks on suid bones ${ }^{19,40}$. These clues suggest that with early farmers of the Levantine PPNA culture, came the earliest evidence of house mouse stowaway transport onto an island. Our results confirm the presence of $M$. $m$. domesticus in large numbers during the PPNB colonization of Cyprus (Kissonerga-Mylouthkia) up to 8,000 cal BP in Khirokitia, on the southern coast of Cyprus, and in Cape Andreas-Kastros, on the northeastern tip of the Khyrenia Peninsula, indicating the successful settlement of commensal populations of M. m. domesticus throughout the island (Fig. 1d, Supplementary Methods S5).

Between 10,000 and 8,000 cal BP, M. m. domesticus spread inland from the Levantine cradle towards the upper Euphrates valley in the Taurus foothills (Çafer Höyük), southern Zagros (Ganj Dareh) and the Konya Plain in Anatolia (Çatalhöyük) (Fig. 1e, Supplementary Methods S5). Such inland occurrence has been directly dated (Supplementary Table S6) for Çafer Höyük (between 10,408 and 9,275 cal BP), Ganj Dareh (between 10,174 and 9,431 cal BP) and Çatalhöyük (between 9,399 and 8,452 cal BP).

House mouse dispersal outside the PPN core area. Northward from the PPN core area, we found evidence for the Late Neolithic and Chalcolithic dispersal of $M$. m. domesticus towards Transcaucasia in Norsun Tepe and Ovçular Tepesi, between 5,000 and 4,000 cal BP (Fig. 1f, S5 Fig. 1, Supplementary Methods S5), supporting the role of the Near East in the Neolithic makeup of Transcaucasia ${ }^{28}$. Eastward, we found the presence of M. m. domesticus in the southern Zagros (Tol-e Nourabad) and Iranian Plateau (Tepe Zagheh) between 7,000 and $6,000 \mathrm{cal}$ BP (Fig. 1e, Supplementary Methods S5), which could be due to a local commensalism process rather than the consequence of a dispersal event from the Levant. This suggestion is supported by the occurrence of $M$. $m$. domesticus on the Iranian Plateau since at least the Middle Pleistocene; the mitochondrial genetic distance between Iranian and Near Eastern M. m. domesticus populations ${ }^{41}$; and the genomic divide between the Neolithic human populations of Anatolia and the Zagros region ${ }^{42}$.

Westward, towards the Eastern Mediterranean and continental Southeastern Europe, we have no evidence of a Neolithic dispersal of M. m. domesticus beyond Cyprus (Fig. 1f, Supplementary Methods S5). All of the ten samples from Early, Middle and Late Neolithic contexts from continental Greece have been identified as the autochthonous "wild" phenotype (Mus macedonicus) with GMM and Cytochrome $b$ (Supplementary Table S6) and directly dated at Mavropigi (8,455 - 7,329 cal BP) and Avgi (7,424-7,175 cal BP). These results support the absence of a maritime Neolithic dispersal of house mouse towards the Eastern Mediterranean and continental Southeastern Europe further west than Cyprus during the 11-10 ${ }^{\text {th }}$ millennia cal BP. Secondly, they show that the Neolithic spread through the southern Aegean islands and Northern Greece during the $9^{\text {th }}$ millennium cal BP ${ }^{43-45}$ did not act as a vector of house mouse dispersal towards Southeastern Europe.

In Aegean contexts, the occurrence of M. m. domesticus is only documented from the Bronze Age (Fig. 1f, SI Fig. 1), where it occurs in all the Early, Middle and Late Bronze Age contexts of urban sites in Crete (GSE, Chania, Mochlos, and Malia) and Santorini (Akrotiri), strongly supporting the absence of house mouse in Neolithic contexts $^{17}$. Its occurrence in Akrotiri is confirmed by the Cytochrome $b$ identification dated between 4521 and $3,864 \mathrm{cal}$ BP (Supplementary Table S6). This ubiquity of M. m. domesticus in all the Aegean Bronze Age contexts 
of our dataset suggests that the invasive process of domesticus in the Eastern Mediterranean was driven mainly by Bronze Age maritime networks, which is directly confirmed by the house mouse mandible found in the cargo of the Late Bronze Age Uluburun shipwreck off the southern shores of Anatolia ${ }^{46}$.

Although we could have expected $M . m$. domesticus to first invade the European continent, fostered by the Neolithic and Bronze Age connectivity with the Near East, we found instead that M. m. musculus was the first house mouse to spread into continental southern Europe at the end of the Neolithic (Fig. 1f, Supplementary Methods S5). Its occurrence is documented from Late Neolithic / Chalcolithic household deposits (mid $7^{\text {th }} \mathrm{mil}-$ lennium BP) from tell sites in Southeastern Romania (Bucșani) and Serbia (Vinča-Belo Brdo). Its identification has been confirmed in Bucșani by ancient Cytochrome $b$ sequences, secured for six specimens and a direct radiocarbon dating between 6,627 and 6,413 cal BP (Supplementary Table S6). The M. m. musculus remains in Vinča-Belo Brdo have not been directly dated but they have been sampled from a deposit that derives from a fire event confidently dated to $6510-6460$ cal $\mathrm{BP}^{47}$. The occurrence of commensal musculus has also been documented in Turkmenistan by 3,000 cal BP, with the remains of musculus being found in a storage jar from the proto-urban tell site of Ulug Depe (Fig. 1f, Supplementary Methods S5).

\section{Discussion}

Upper Pleistocene range expansion of house mice in Southwest Asia. Speciation models from modern mitochondrial markers suggest that the range expansion of $M$. $m$. domesticus in the Mesopotamian area took place at some point during the Middle Pleistocene ${ }^{48}$. Our study found occurrence of M. m. domesticus in the Upper Pleistocene ecosystem of the southwestern Iranian Plateau29,confirming a long-lasting natural occurrence of these lineages in this area ${ }^{11,12}$. Yet, we only found occurrence of M. m. domesticus in the Southern Levant from $14,500 \mathrm{cal} \mathrm{BP}$, and in Northern Levant from 12,000 cal BP. In addition, its absence from numerous Middle and Upper Pleistocene non-anthropogenic cave deposits in the Southern Levant ${ }^{15,39}$ suggests that the natural range expansion of M. m. domesticus which took place in the ecological gradient of the Euphrates-Tigris River Basin, only reached the Levant after the Last Glacial Maximum ${ }^{49}$, in keeping with the phylogeographic reconstruction derived from mitochondrial data ${ }^{41}$ and its probable dating ${ }^{48}$. A suitable climatic refuge that could have occurred in the relatively lower altitude areas of the Euphrates-Tigris River Basin should be investigated.

The origin of house mouse synanthropy. The earliest commensal populations of M. m. domesticus found in Natufian sedentary settlements $(14,500 \mathrm{cal}$ BP) confirm that the impact of sedentism on ecosystems and the ecology of organisms (i.e. reduction of predation and competition pressures, climatic buffer etc ${ }^{15,50,51}$ ) was the catalyst for the commensal relationship between mice and humans rather than the emergence of agriculture systems with large-scale grain storage ${ }^{14,16}$, which emerged two millennia later. Nevertheless, M. m. domesticus was identified only in the largest, long-term Natufian settlements such as 'Ain Mallaha in the Southern Levant and Mureybet in the Northern Levant between 14,500 and 12,000 BP. In smaller and shorter term Natufian sites in the Southern Levant, only the native mouse Mus macedonicus was identified ${ }^{15,17,39}$. This pattern suggests that dense human occupation in large open air settlements was the prerequisite for $M$. $m$. domesticus to eventually outcompete other potential anthropophilous rodent like M. macedonicus from the Natufian ecological niche ${ }^{15}$.

The occurrence of M. m. domesticus in all the PPNA and Early and Late PPNB contexts of our dataset in the Zagros, Levant, Anatolia, and Cyprus, suggests that the emergence of the agricultural system was the key driving force in the house mouse's commensal trajectory. PPNA plant cultivation of wild cereals and pulses ${ }^{52-54}$ correlates $^{-1}$ with the emergence of the first settlement with communal buildings and cereal storage ${ }^{55,56}$, marking a substantial increase in the degree of sedentism of human societies. PPNB plant and animal domestication, which entails a greater reliance on cereals ${ }^{57}$ and storage ${ }^{14,58}$, correlates with an increase in settlement sizes from less than two hectares, during the PPNA, to more than 10 hectares during the Late PPNB ${ }^{16,59}$. All these factors prompted the development of proto-urban environments with a unique anthropogenic ecosystem disturbance ${ }^{60}$, fostering the subsequent adaptedness of the house mouse to such altered human environments ${ }^{61}$. With regards to agriculture, the villages and buildings provided greater protection against predators and competitors, a buffer from temperature fluctuation, and a constant food supply due to large scale grain storage from the PPNA ${ }^{53,56}$ onwards, driving M. m. domesticus to become an anthro-dependent organism ${ }^{62}$.

House mouse dispersal in Southeastern Europe. After a steady dispersal throughout the PPN core area, including Cyprus, from two potential commensal epicentres in the Northern and Southern Levant, the house mouse dispersal did not follow the spread of Neolithic culture towards Europe through the Aegean islands or the Bosphorus. According to our current data, the dispersal of M. m. domesticus outside the PPN core area did not reach the Aegean before the Bronze Age (4,000 years ago), suggesting that dispersal barriers might have prevented its biological invasion of the Aegean and continental Europe along with the Neolithic dispersal of domestic animals and plants ${ }^{63}$.

The biological invasion model of $M . m$. domesticus towards the Aegean and continental Greece could be understood according to a "mainland-island" metapopulation structure ${ }^{64}$, based on long distance dispersal from source populations in the PPN core area. To be successful during the Neolithic, this biological invasion would have required a sustainable local environment for house mouse metapopulations to thrive and disperse, as well as a migrant flow from the source to maintain them. To explain the absence of house mouse Neolithic dispersal outside the PPN core area, we consider that neither the ecological niche nor the migrant flow could sustain this biological invasion model. Before about 7,000 BP, most of the Neolithic communities in Greece and Northern Balkans lived in small settlements lacking communal storage facilities ${ }^{58,65-67}$. Furthermore, our study proved that indigenous rodents such as Mus macedonicus or M. spicilegus, occupied the commensal niche in the south Balkan peninsula at least, acting as a competitive barrier. Only the intensification of maritime trade with the Near East 
driven by Bronze Age cities ${ }^{43,68}$ and the increasing size and stability of settlements associated with this migrant flow could have sustained M. m. domesticus metapopulations in the Aegean and the Balkan peninsula ${ }^{69}$.

The earliest house mouse dispersal in Europe was achieved by M. m. musculus, colonizing Eastern Europe at the end of the Neolithic, 6,500 years ago. Our understanding of the origin of M. m. musculus subspecies from phylogeographic studies is still very limited ${ }^{9}$. From the different debated points of origin of this subspecies, in the southern or northern Caucasus ${ }^{10,70,71}$, a human dispersal with the advance of agriculture into Europe through the Pontic Steppe north of the Black Sea has been considered the most parsimonious ${ }^{9}$. However this phylogeographic scenario does not fit with the archaeological understanding of the agricultural dispersal considered to enter into Europe through the Balkans and then reaching the Pontic steppes from the western Black Sea shores between the $7^{\text {th }}$ and $6^{\text {th }}$ millennium $\mathrm{BP}^{72}$. Our current dataset cannot rule out a dispersal route of $M . m$. musculus along the southern Black Sea coasts and through the Bosphorus. However, a natural expansion range of M. m. musculus into the Pontic steppe through Transcaucasia or Turkmenistan is likely to have happened from the Late Glacial warm up. Indeed, unlike $M$. m. domesticus, this sub-species has greater non-commensal abilities that could have allowed it to spread in the Pontic steppes without any facilitation from the human niche construction. Then, when the Neolithisation reached the Pontic steppes from the west by the $7^{\text {th }}$ millennium BP, the Neolithic settlements could act as a commensalism center for musculus, much like the PPN niche construction in the Levant did for $M$. $m$. domesticus. This assumption needs to be demonstrated through investigation of small mammal remains from early Neolithic settlements in Ukraine to document its commensalism, as well as through a comparison with late Pleistocene/early Holocene small mammal remains documenting the Pontic biodiversity before the Neolithic. Then, the development of large proto-urban centers, such as the large Tripolye settlements from the Dnieper river to the Carpathians, stemming from a broader context of large late-Neolithic settlements and the exchange networks stretching from eastern Croatia to Ukraine, could have both facilitated the dispersal of M. m. musculus metapopulations reaching as far as southeastern Romania (Bucșani) and Serbia (Vinča-Belo Brdo).

Could the house mouse dispersal scenario help elucidate early cat domestication?. The cat domestication process was historically thought to have been initiated alongside the development of agriculture 6,000 years ago in the Nile valley, when mouse proliferation in villages attracted commensal populations of small felids ${ }^{21,73}$. However, research on the last 12,000 years of human impact on Cyprus' vertebrate diversity has provided insights into a greater time depth for the human-cat relationship. Cyprus is an oceanic island which has remained remote from the continent since the Miocene ${ }^{74}$. Its endemic fauna, which included only one carnivorous species, a genet (Genetta plesictoides), was exctinct before the arrival of Neolithic settlers 11,000 years ago; except for the endemic Cypriot mouse (Mus cypriacus) that is still extant today ${ }^{36}$. Zooarchaeological evidence from the PPNA site of Klimonas showed that early Neolithic colonisers introduced specimens of Felis silvestris cf. lybica to Cyprus at least 11,000 years ago ${ }^{40}$. This human dispersal of small felids, acting likely as commensals control, is associated with the earliest evidence for the presence of M. m. domesticus in Cyprus (as shown by our study) and with the earliest cereal cultivation on the island ${ }^{75}$. The earliest evidence for domestic cat in Cyprus, however, comes 9,000 years ago at the PPNB site of Shillourokambos. Here, a complete skeleton of Felis silvestris lybica ${ }^{25} 18 \%$ bigger than its wild relatives in Cyprus and on the continent ${ }^{19}$, was found in association with a human burial ${ }^{25}$, suggesting a tight relationship between the deceased and the cat ${ }^{25}$. The human dispersal in Cyprus of human-controlled individuals of Felis silvestris cf. lybica 11,000 years ago, potentially to control house mouse pests, and the occurrence of domestic specimens of Felis silvestris lybica from 9,000 BP, strongly suggest that the cat domestication process was already underway in the Levant, at least five millennia before the earliest evidence of cat domestication in Egypt ${ }^{19}$.

Since cats are strictly carnivorous, evolved for preying on small terrestrial vertebrates and birds, it is widely accepted that humans have taken advantage of these phenotypic traits to control rodent pests in their grain storage and to hunt birds ${ }^{19}$. For these reasons it is widely assumed that the commensal pathway of cat domestication has been triggered by the presence of commensal populations of rodents within human dwellings ${ }^{27}$. Therefore our identification of many commensal M. m. domesticus in the Early Natufian village of 'Ain Mallaha could provide an indirect clue for a cat commensal pathway initiated as early as $14,500 \mathrm{BP}$ in the Southern Levant, 4,000 years before the beginning of agriculture. This hypothesis of opportunistic commensal small felids in the vicinity of Natufian sedentary settlements is supported by the scarce occurrence of Felis silvestris ssp. remains that were collected from Natufian and Khiamian levels at Hatoula ${ }^{76}$, Mureybet ${ }^{77}$ and the Late Natufian site of Ein Gev II ${ }^{78}$. Unidentified Felis remains in the Natufian site of 'Ain Mallaha ${ }^{79}$ and Iraq ed-Dubb in Jordan ${ }^{80}$ have also been recorded. To support this hypothesis, greater efforts need to be undertaken in the taxonomic identification of small felid remains associated with the Natufian settlements of the Levant, combining the latest advances in morphometric, proteomic or genomic approaches where possible.

Paleogenetic studies provide clear evidence that the first human mediated dispersal of $F$. s. lybica towards Europe stemmed from Anatolia, spreading towards current Bulgaria by 6,400 cal BP, Romania by 5,200 cal BP24 and up to Poland by 5,000 cal $\mathrm{BP}^{81}$. Yet, archaeological evidence from Kastanas $(3,300 \mathrm{cal} \mathrm{BP})$ suggests that cat dispersal only reached continental Greece during the Late Bronze Age ${ }^{24,82}$. As cats are strict carnivores specialised in rodent predation and because they were mostly appreciated by humans for fighting against murid pests ${ }^{20,21,83}$, it is very likely that the anthropogenic dispersal of domestic F. s. lybica to Europe during the Late Neolithic / Chalcolithic was driven by the need for rodent pest control in the Balkan peninsula. Therefore, the timing of the invasive process of house mice in Europe that we have documented here can provide elements of understanding for the tempo of these two cat dispersal pulses into Southeastern Europe.

We propose as a hypothesis that the earliest cat dispersal towards Europe was driven by M. m. musculus biological invasion during the Late Neolithic/Chalcolithic, when the size of the proto-urban settlements and the catchment for grain production generated rodent pests and therefore the need to tackle them with cat predation. The later dispersal in continental Greece on the other hand could have been pushed by the later M. m. domesticus 
dispersal associated with the development of Bronze Age urbanisation and the need for pest control in the Balkan peninsula. House mouse is indeed documented on Crete from this study in the port cities of Mochlos ${ }^{84}$, Malia and Chania by 3,900-3,700 cal BP and in Kommos during the same period ${ }^{85}$. It reached continental Greece later as suggested by its earliest occurence at the site of Nichoria in the Peloponnese ${ }^{17}$. The presence of cats on Crete by the Late Bronze Age is supported by various iconographic representations, such as the reliefs of miniature cats on vessel bodies also found in the port towns of Malia ${ }^{86}$, which could indicate that the Cretans had known or acquired cats through their established connections with Egypt ${ }^{87}$. To support this hypothesis of two domestic cat dispersal routes out of Southwest Asia, at the end of the Neolithic in the Balkans and during the Bronze Age in the Greek peninsula, an extensive survey for cat remains associated with direct radiocarbon dating and high-throughput paleogenetics analyses to capture recent phylogeographic lineages within F.s.lybica needs to be pursued.

\section{Conclusion}

The bioarchaeological evidence generated here has revealed new insights into the origin of the biological invasion of the two house mouse sub-species in Southwestern Asia and Europe as well as indirect clues on the earliest steps of cat domestication and dispersal towards Europe. They suggest a natural range expansion of $M$. m. domesticus in the ecological gradient of the Tigris-Euphrates Basin up to the eastern Mediterranean coasts during the Late Pleistocene, stemming from the Zagros. In the Levant, sedentism of Natufian communities created the ecological niche that promoted the commensal behaviour of M. m. domesticus populations from 14,500 BP, and potentially the commensal pathway of cat domestication. However, this synanthropic behaviour was restricted to large and densely populated proto-village environments and potentially happened independently in the Southern and Northern Levant. It is only with the advance of the PPN agricultural ecosystem and its proto-urban environments, denser human populations and greater human movements, that the biological invasion by M. m. domesticus happened in the Near East and up to the remote island of Cyprus, where the house mouse, and human-controlled commensal cats, followed the earliest maritime transport of the PPNA ecosystem by 10,800 BP.

Curiously, the Neolithic dispersal stemming from the Near East along the Mediterranean and the Bosphorus routes did not foster the house mouse invasion of Europe. The first invasive wave by M. m. musculus happened during the Late Neolithic / Chalcolithic, when it reached south-eastern Europe by 6,500 BP. After a natural range expansion into the Pontic Steppes from the Late Glacial, M. m. musculus likely became commensal when Neolithic settlements reached the Pontic steppes from Southeastern Europe by 7,000 BP. Then, the inland dispersal of $M . m$. musculus into Europe was facilitated by human movements along transport and exchange networks. The second invasive wave by M. m. domesticus only penetrated the Aegean by 4,000 BP when the intensification of Bronze Age maritime trade with the Near East and the emergence of urban environments fostered sustainable metapopulation structures. This invasive process by the two commensal house mice and their pressure on grain storage of farming communities could have significantly contributed to the first dispersal waves of domestic cats into Europe.

The models of origin and dispersal for the two house mouse sub-species in Southwestern Asia and Europe generated by this study need to be further tested using high-throughput sequencing and paleogenomic approaches. Retrieving mitochondrial haplotypes from ancient house mouse will produce dated phylogeographic inferences about the colonization history of both sub-species in Europe and indirect clues about past human dispersal and trading networks. Genome-wide studies of ancient commensal populations across Southwestern Asia and along a time series from the Late Glacial to the Iron Age will potentially allow the investigation of (1) the genetic signatures for the behavioural selection involved in the commensalism process, (2) specific phenotypic traits separating $M$. musculus sub-species from other wild species dwelling around the Mediterranean, such as the tail length, longer in M. musculus sub-species and (3) the amount of genetic isolation and introgression with autochtonous Mus species involved in the evolutionary process of the house mouse.

\section{Methods}

Geometric morphometrics. The acquisition of GMM data for the molar shape analysis of the first lower molars ( $\mathrm{m} 1$ ) was performed on 2D images of the occlusal view of the $\mathrm{m} 1$, following an already published proto$\mathrm{Col}^{28}$. The images were acquired by a Leica EZ4D stereoscope digital camera and the LAS operating software. The $2 \mathrm{D}$ external outline of the occlusal view of the $\mathrm{m} 1$ was recorded using tpsDig v. $2.30^{88}$.

The phenotypic similarities between the current Mus sibling species ${ }^{89}$ (Fig. 1a) forced us to find the best GMM method to capture the taxonomic signal from the $\mathrm{m} 1$ outline by comparing the classification performances of four mathematical representations and three approaches of the dental outline measurements. The four mathematical representations are two semi-landmark alignment ${ }^{90}$ methods (Bending Energy Minimization (BEM) and Procrustes Distance Projection (PDP)) and two Elliptic Fourier ${ }^{91}$ methods (Procrustes Aligned Elliptic Fourier (EFAproc) and Normalized Elliptic Fourier $(\mathrm{NEF})^{92}$ ). The three methods for the $\mathrm{m} 1$ outline data acquisition were: one landmark and 63 semi-landmarks ${ }^{15,28}$, six landmarks on the cusps maximum of curvature and 52 semi-landmarks on the rest of the curves, five landmarks on the maximum of curvature between the cusps (valleys) and 48 semi-landmarks. The taxonomic performance of each approach was assessed over a training set of 30 M. m. domesticus, 30 M. m. musculus, and 20 M. macedonicus specimens. We used the classification method from the Linear Discriminant Analysis (LDA) including a leave-one-out cross validation on a reduced shape dataset $^{90,93}$ using R libraries (MASS, Momocs, Geomorph, shapes) and $\mathrm{R}$ functions (see ${ }^{92}$ ). The results suggested that the BEM methods applied on outlines with 1 landmark and 63 semi-landmarks to be the most efficient geometric morphometric approach in capturing the taxonomic signal required for this study (Supplementary Table S7). The BEM method was therefore applied for the whole dataset.

To assess the numerical taxonomy of the archaeological samples we performed the analysis in several steps. First, the potential occurrence of sympatric wild and commensal subspecies in each of the 43 archaeological 
deposits was explored using a Bayesian model based clustering approach ${ }^{94}$, to avoid pooling two taxa within the same "population" grouping factor (i.e. site name) (Supplementary Table S8). Then we assessed the phenotypic differences and affinities among the modern and archaeological "population" samples using MANOVA and Canonical Variate Analysis (CVA), after dimensionality reduction ${ }^{90,93}$ using R library MASS ${ }^{95}$. And finally, to identify the taxonomic status of each archaeological "population" mean shape in the discriminant morphospace (CV1-CV2), we used the machine learning k-nearest neighbours (KNN) algorithm using four taxonomic units as training vectors: the three $M$. musculus subspecies and one non-commensal group including $M$. macedonicus, M. spicilegus and M. cypriacus. The number of $k$ values was determined by the square root of $N$. KNN machine learning was performed using R library Class ${ }^{95,96}$.

Paleogenetic analysis. Samples for ancient DNA analyses consisted mostly of the extracted molars from the hemi-mandibles used for paleogenetic and radiocarbon dating analyses. DNA extractions and analyses of ancient samples were performed in a dedicated clean room facility at the Musée de l'Homme (Plateau de Paléogénomique et Génétique Moléculaire, MNHN) where no previous work on either modern or ancient mouse DNA has been performed. Modern and standard experiments were performed in the Service de Systématique Moléculaire (MNHN, Paris). The total amount of tooth material per specimen ranged from 2 up to $12 \mathrm{mg}$ (mean $4.5 \mathrm{mg}$ ). For several specimens some bone material was used instead of teeth (range 10-21.5 mg, mean $17.5 \mathrm{mg}$ ). DNA extractions were performed using the PrepFiler BTA Forensic DNA Kit (Life Technologies) according to the manufacturer's recommendations (with a final elution volume of $35 \mu \mathrm{l}$ ). Lysis was performed via the direct digestion of complete extracted teeth (without prior crushing).

We investigated the amplifiability of mouse DNA through absolute quantification using qPCR (CFX-96 real-time thermal Cycler, Bio-Rad technologies) and a series of three nested PCR fragments of the cytochrome $b$ gene: 65, 92 and 133 bp (Supplementary Table S9). Despite being less variable than the more documented mitochondrial D-loop region, the cytochrome $b$ gene allows the design of PCR primers that enable the amplification of very short fragments (the hypervariable region of the control region spans more than $300 \mathrm{bp}$ in mice which prevents such design ${ }^{48}$ ). Furthermore, Suzuki et al. ${ }^{97,98}$ have shown that the overall phylogenetic signal is congruent between the mitochondrial D-loop and the cytochrome $b$ gene, with the same five main haplogroups being recognized within $M$. musculus. We designed the qPCR primers based on formerly published material for the cytochrome $b$ gene from both house mouse and wild mice species ${ }^{97}$. All primer pairs excluded human amplification thanks to numerous mismatches in priming sites (Supplementary Table S10), even when the PCR reactions were spiked with up to $10 \mu \mathrm{g}$ of human DNA. We produced a quantitation standard (using a modern mouse sample as a template DNA for the $133 \mathrm{bp}$ fragment) to address the sensitivity of the assay (from 1 million down to 1 copy per $\mu$ l of extract): all three assays were optimized for the same annealing temperature and sensitized down to $2-5$ copies per $\mu \mathrm{l}$ (Supplementary Table S11). We designed these assays in order to maximize their discrimination power at two taxonomic scales. Firstly, they allow for a strict diagnosis of each of the three wild species $(M$. spicilegus, M. macedonicus and M. cypriacus) versus the commensal forms (Supplementary Table S12). Secondly, we could discriminate between the known modern haplogroups of M. m. musculus and M. m. domesticus thanks to 1, 2, and 3 fixed positions in the three nested amplicons respectively (Supplementary Table S12). PCR reactions were carried out in $25 \mu \mathrm{l}$ using $1 \mathrm{X}$ SsoAdvanced Supermix (Bio-Rad Technologies), $200 \mu \mathrm{M}$ of each forward and reverse primer (Supplementary Table S11), and $1 \mu \mathrm{l}$ of DNA extract. Reaction conditions were as follows: $2 \mathrm{~min}$ initial denaturation at $95^{\circ} \mathrm{C}$, then 40 cycles of $10 \mathrm{~s}$ denaturation at $95^{\circ} \mathrm{C}, 15 \mathrm{~s}$ at $58^{\circ} \mathrm{C}$ and $20 \mathrm{~s}$ at $72{ }^{\circ} \mathrm{C}$. PCR results are summarized in Supplementary Table S11.

DNA sequencing of the positive PCR products were performed on a $3130 \mathrm{ABi}$ automated sequencer with BigDye v1.1, using extended sequencing primers to allow for the sequence determination of short amplicons ${ }^{99}$. Only haplotypes validated through at least two independent PCRs were considered in the manuscript (see Supplementary Table S11 for details).

AMS dating. Collagen extraction of the samples weighed between 6.5 and $36.9 \mathrm{mg}$, followed the protocol of Cersoy et al. ${ }^{100}$. For this study we shortened the duration of the bone demineralization and the collagen purification to minimize collagen degradation or loss. The quality control parameters $(\% \mathrm{C}, \% \mathrm{~N}$, and $\mathrm{C} / \mathrm{N}$ ratios $)$ reported here were measured in this EA and did not require an extra sample to be taken.

Depending on collagen weight, samples were either graphitized or transferred to the gaseous phase $\left(\mathrm{CO}_{2}\right)$. Heavy samples ( $>0.2 \mathrm{mgC}$ ) were combusted and graphitized using an AGE3 device (Ion plus, Switzerland) ${ }^{101}$. In order to reduce the risk of memory effects in the graphite reactors, a sample of about the same age was combusted prior to each archaeological sample. Ultra-light samples $(<0.2 \mathrm{mgC})$ were combusted and graphitized online using a GIS device ${ }^{102,103}$. To improve the accuracy of the measurement in the gaseous phase (usually lower than for the graphitized samples), samples MT 58, MT 61, MT 78 and MT 81 were measured in duplicates.

All the Mus sp. samples were dated using the compact AMS ECHoMICADAS ${ }^{104}$. Data reduction was performed using BATS software (version 4.07) ${ }^{105}$. Oxalic acid II NIST standard and phthalic anhydride blanks were measured, for each individual run, to allow normalization, correction for fractionation and background corrections. Intercomparison bone samples (VIRI F, VIRI I VIRI H and VIRI E - for further details see ${ }^{106}$ - spanning the full range of radiocarbon were also prepared and radiocarbon dated. The radiocarbon ages were calibrated using OxCal software ${ }^{107,108}$.

The results are reported in Supplementary Table S6. Collagen yields ranged between 0.8 and $9.1 \%$ and are indicative of poor to moderately well-preserved bones. $\mathrm{C} / \mathrm{N}$ ratios ranged between 3.1 and 3.6, within the 2.9-3.6 limits suitable for radiocarbon dating ${ }^{109}$. Carbon content $[\mathrm{C}]$ of the collagen extracts varied widely, between 0.012 to $1.057 \mathrm{mgC}$. Samples that were dated twice provided similar ages, allowing us to use the R_Combine function in $\mathrm{OxCal}$ to reduce the uncertainty of the calibrated interval. Radiocarbon ages of three intercomparison samples were in good agreement with the consensus values ${ }^{106}$. 


\section{Data availability}

Full morphometric dataset to support the finding of this article can be found online at: https://datadryad.org/ stash/share/W68uF68hDZ8fEDUIR8Psb-6dIZmBbh1UagYAa1809Jw GenBank Number association for the successful ancient DNA sequences have been included in Supplementary Tables S11 and S12.

Received: 22 November 2019; Accepted: 24 April 2020;

Published online: 19 May 2020

\section{References}

1. Boivin, N. L. et al. Ecological consequences of human niche construction: Examining long-term anthropogenic shaping of global species distributions. PNAS 113, 6388-6396 (2016).

2. Ellis, E., Maslin, M., Boivin, N. \& Bauer, A. Involve social scientists in defining the Anthropocene. Nature News 540, 192 (2016).

3. Hershkovitz, I. et al. The earliest modern humans outside Africa. Science 359, 456 (2018).

4. Ricciardi, A. Are Modern Biological Invasions an Unprecedented Form of Global Change? Conservation Biology 21, 329-336 (2007).

5. Bernardo-Madrid, R. et al. Human activity is altering the world's zoogeographical regions. Ecology Letters 22, 1297-1305 (2019).

6. Ellis, E. C. Why Is Human Niche Construction Transforming Planet Earth? RCC Perspectives 63-70 (2016).

7. Lowe, S., Browne, M., Boudjelas, S. \& De poorter, M. World's Worst Invasive Alien Species A selection from the Global Invasive Species Database (2000).

8. Stenseth, N. C. et al. Mice, rats, and people: the bio-economics of agricultural rodent pests. Frontiers in Ecology and the Environment $1,367-375$ (2003).

9. Bonhomme, F. \& Searle, J.B. House mouse phylogeography. In Evolution of the House Mouse (eds. Macholan, M., Baird, SJE, Munclinger, P., Piàlek, J.) 278-296 (Cambrige University Press, 2012).

10. Darvish, J., Orth, A. \& Bonhomme, F. Genetic transition in the house mouse, Mus musculus of Eastern Iranian Plateau. Folia Zoologica 55, 349 (2006).

11. Hamid, H. S., Darvish, J., Rastegar-Pouyani, E. \& Mahmoudi, A. Subspecies differentiation of the house mouse Mus musculus Linnaeus, 1758 in the center and east of the Iranian plateau and Afghanistan. Mammalia 81, 147-168 (2017).

12. Hardouin, E. A. et al. Eurasian house mouse (Mus musculus L.) differentiation at microsatellite loci identifies the Iranian plateau as a phylogeographic hotspot. BMC Evolutionary Biology 15, 26 (2015).

13. Boursot, P., Auffray, J.-C., Britton-Davidian, J. \& Bonhomme, F. The evolution of house mice. Annual Review of Ecology and Systematics 24, 119-152 (1993).

14. Cucchi, T., Auffray, J.-C. \& Vigne, J.-D. History of house mouse synanthropy and dispersal in the Near East and Europe: a zooarchaeological insight. In Evolution in Our Neighbourhood: The House Mouse as a Model in Evolutionary Research (eds. Macholan, M., Baird, S. J. E., Munclinger, P. \& Piàlek, J.) 65-93 (Cambridge University Press, 2012).

15. Weissbrod, L. et al. The origins of house mice in ecological niches created by settled hunter-gatherers in the Levant $15,000 \mathrm{y}$ ago. PNAS 114, 4099-4104 (2017).

16. Fuller, D. Q. \& Stevens, C. J. Open for Competition: Domesticates, Parasitic Domesticoids and the Agricultural Niche. Archaeology International 20, 110-121 (2017).

17. Cucchi, T., Vigne, J.-D. \& Auffray, J.-C. First occurrence of the house mouse (Mus musculus domesticus Schwarz \& Schwarz, 1943) in the Western Mediterranean: a zooarchaeological revision of subfossil occurrences. Biological Journal of the Linnean Society 84, 429-445 (2005).

18. Cucchi, T. et al. New insights into the invasive process of the eastern house mouse (Mus musculus musculus): Evidence from the burnt houses of Chalcolithic Romania. The Holocene 21, 1195-1202 (2011).

19. Vigne, J.-D. The beginning of cat domestication in East and West Asia. In Animals: Cultural Identifiers in Ancient Societies? (eds. Peters, J., McGlynn, G. \& Goebel, V.) 343-354 (Documenta archaeobiologiae, 2019).

20. Clutton-Brock, J. Cats, ancient and modern. (Harvard University Press, 1993).

21. Malek, J. The cat in ancient Egypt. (University of Pennsylvania Press, 1997).

22. Zeuner, F. E. A history of domesticated animals. (Harper \& Row, 1963).

23. Driscoll, C. A. et al. The Near Eastern origin of cat domestication. Science 317, 519-523 (2007).

24. Ottoni, C. et al. The palaeogenetics of cat dispersal in the ancient world. Nature Ecology \& Evolution 1, 1-7 (2017).

25. Vigne, J.-D., Guilaine, J., Debue, K., Haye, L. \& Gérard, P. Early Taming of the Cat in Cyprus. Science 304, 259 (2004).

26. Cucchi, T., Vigne, J.-D., Auffray, J.-C., Croft, P. \& Peltenburg, E. Introduction involontaire de la souris domestique (Mus musculus domesticus) à Chypre dès le Néolithique précéramique ancien (fin IX ${ }^{e}$ et VIII ${ }^{e}$ millénaires av. J.-C.). Comptes Rendus Palevol $\mathbf{1}$, 235-241 (2002).

27. Faure, E. \& Kitchener, A. C. An archaeological and historical review of the relationships between felids and people. Anthrozoös 22, 221-238 (2009).

28. Cucchi, T. et al. On the trail of Neolithic mice and men towards Transcaucasia: zooarchaeological clues from Nakhchivan (Azerbaijan). Biological Journal of the Linnean Society 108, 917-928 (2013).

29. Biglari, F. et al. Test excavations at the Middle Paleolithic sites of Qaleh Bozi, Southwest of Central Iran, A preliminary report. In Iran Palaeolithic (eds. Otte, M., Biglari, F. and Jaubert, J.) 29-38 (BAR International Series 1968, 2009).

30. Scott, J. E. \& Marean, C. W. Paleolithic hominin remains from Eshkaft-e Gavi (southern Zagros Mountains, Iran): description, affinities, and evidence for butchery. Journal of Human Evolution 57, 248-259 (2009).

31. Shidrang, S. The Middle to Upper Paleolithic Transition in the Zagros: The Appearance and Evolution of the Baradostian. in The Middle and Upper Paleolithic Archeology of the Levant and Beyond (eds. Nishiaki, Y., Akazawa, T.) 133-156 (Springer, 2018).

32. Manca, L., Mashkour, M., Shidrang, S., Averbouh, A. \& Biglari, F. Bone, shell tools and ornaments from the Epipalaeolithic site of Ali Tappeh, East of Alborz Range, Iran. Journal of Archaeological Science: Reports 21, 137-157 (2018).

33. McBurney, C. B. M. \& Payne, R. The Cave of Ali Tappeh and the Epi-Palaeolithic in N.E. Iran. Proceedings of the Prehistoric Society 34, 385-413 (1969).

34. Simmons, A. Akrotiri-Aetokremnos (Cyprus) 20 years later: an assessment of its significance. Eurasian Prehistory 10, 139-156 (2013).

35. Simmons, A. Faunal Extinction in an Island Society: pygmy hippopotamus hunters of Cyprus. (Kluwer Academis Publishers, 1999).

36. Cucchi, T. et al. A new endemic species of the subgenus Mus (Rodentia, Mammalia) on the Island of Cyprus. Zootaxa 1241, 1-36 (2006).

37. Bate, D. M. A. The mammals of Cyprus. Proceedings of the Zoological Society of London 2, 341-348 (1903).

38. Boekschoten, G. J. \& Sondaar, P. Y. On the fossil mammalia of Cyprus, I \& II. Proceedings of the Koninklijke Nederlandse Akademie van Wetenschappen (Series B) 75, 306-38 (1972).

39. Cucchi, T. Le commensalisme de la souris et les sociétés néolithiques méditerranéennes. Unpublished PhD of the Natural History Museum of Paris https://tel.archives-ouvertes.fr/tel-00363186 (2005).

40. Vigne, J.-D. et al. Klimonas, a late PPNA hunter-cultivator village in Cyprus: new results. in Nouvelles données sur les débuts du Néolithique à Chypre vol. 9 21-46 (Société préhistorique française, 2017). 
41. Rajabi-Maham, H., Orth, A. \& Bonhomme, F. Phylogeography and postglacial expansion of Mus musculus domesticus inferred from mitochondrial DNA coalescent, from Iran to Europe. Molecular Ecology 17, 627-641 (2008).

42. Broushaki, F. et al. Early Neolithic genomes from the eastern Fertile Crescent. Science 353, 499 (2016).

43. Broodbank, C. The making of the Middle Sea: a history of the Mediterranean from the beginning to the emergence of the Classical world. (Oxford University Press, 2013).

44. Broodbank, C. An island archaeology of the early Cyclades. (Cambridge University Press, 2002).

45. Perlès, C. The Early Neolithic in Greece. (Cambridge University Press, 2001).

46. Cucchi, T. Uluburun shipwreck stowaway house mouse: molar shape analysis and indirect clues about the vessel's last journey. Journal of Archaeological Science 35, 2953-2959 (2008).

47. Tasic, M. et al. Vinča-Belo Brdo, Serbia: The times of a tell. Germania 93, 1-75 (2016).

48. Bonhomme, F. et al. Genetic differentiation of the house mouse around the Mediterranean basin: matrilineal footprints of early and late colonization. Proceedings of the Royal Society of London B: Biological Sciences 278, 1034-1043 (2011).

49. Auffray, J.-C., Vanlerberghe, F. \& Britton-Davidian, J. The house mouse progression in Eurasia: a palaeontological and archaeozoological approach. Biological Journal of the Linnean Society 41, 13-25 (1990).

50. Auffray, J.-C., Tchernov, E. \& Nevo, E. Origine du commensalisme de la souris domestique (Mus musculus domesticus) vis-à-vis de l'homme. Comptes rendus de l’Académie des sciences. Série 3. Sciences de la vie 307, 517-522 (1988).

51. Tchernov, E. Commensal animals and human sedentism in the Middle East. Animals and archaeology 3, 91-115 (1984).

52. Colledge, S., Conolly, J., Finlayson, B. \& Kuijt, I. New insights on plant domestication, production intensification, and food storage: the archaeobotanical evidence from PPNA Dhra. Levant 50, 14-31 (2018).

53. Kuijt, I. \& Finlayson, B. Evidence for food storage and predomestication granaries 11,000 years ago in the Jordan Valley. PNAS 106, 10966-10970 (2009).

54. Willcox, G. \& Stordeur, D. Large-scale cereal processing before domestication during the tenth millennium cal BC in northern Syria. Antiquity 86, 99-114 (2012)

55. Mithen, S. J. et al. An 11600 year-old communal structure from the Neolithic of southern Jordan. Antiquity 85, 350-364 (2011).

56. Stordeur-Yedid, D. Le village de Jerf el Ahmar: Syrie, 9500-8700 av. J.-C.: l'architecture, miroir d’une société néolithique complexe. (CNRS, 2015).

57. Maeda, O., Lucas, L., Silva, F., Tanno, K.-I. \& Fuller, D. Q. Narrowing the harvest: Increasing sickle investment and the rise of domesticated cereal agriculture in the Fertile Crescent. Quaternary Science Reviews 145, 226-237 (2016).

58. Kuijt, I. Home is where we keep our food: The origins of agriculture and late Pre-Pottery Neolithic food storage. Paléorient 37.1, 137-152 (2011).

59. Kuijt, I. Demography and storage systems during the southern Levantine Neolithic demographic transition. The Neolithic demographic transition and its consequences (eds. Bocquet-Appel, J.-P. \& Bar-Yosef, O.) 287-313 (Springer, 2008).

60. Johnson, M. T. J. \& Munshi-South, J. Evolution of life in urban environments. Science 358 (2017).

61. McDonnell, M. J. \& Hahs, A. K. Adaptation and Adaptedness of Organisms to Urban Environments. Annu. Rev. Ecol. Evol. Syst. 46, $261-280(2015)$

62. Hulme-Beaman, A., Dobney, K., Cucchi, T. \& Searle, J. B. An Ecological and Evolutionary Framework for Commensalism in Anthropogenic Environments. Trends in Ecology \& Evolution 31, 633-645 (2016).

63. Arbuckle, B. S. et al. Data Sharing Reveals Complexity in the Westward Spread of Domestic Animals across Neolithic Turkey. Plos One 9, e99845 (2014).

64. Hanski, I. \& Gilpin, M. Metapopulation dynamics: brief history and conceptual domain. Biological Journal of the Linnean Society 42, 3-16 (1991).

65. Halstead, P. Neighbours from hell? The household in Neolithic Greece. In Neolithic Society in Greece (ed. Halstead, P.) 77-95 (Sheffield University Press, 1999).

66. Souvatzi, S. G. A social archaeology of households in Neolithic Greece. (Cambrige University Press, 2008).

67. Chapman, J. Houses, Houseolds, Villages, and Proto-Cities in Southeastern Europe. in The lost World of Old Europe. The Danube Valley, 5000-3500 BC 74-89 (ed. Anthony David W.) 74-89 (Princeton University Press, 2010).

68. Doumas, C. G. A. Akrotiri. In The Oxford Handbook of the Bronze Age Aegean (ca. 3000-1000 BC) (ed. Cline E.H.) 752-761 (Oxford University Press, 2010).

69. Hanski, I. Metapopulation dynamics. Nature 396, 41-49 (1998).

70. Mezhzherin, S. V., Kotenkova, E. V. \& Mikhailenko, A. G. The house mice, Mus musculus sl, hybrid zone of Transcaucasus. Zeitschrift fur Saugetierkunde 63, 154-168 (1998).

71. Milishnikov, A. N., Lavrenchenko, L. A. \& Lebedev, V. S. Origin of the house mice (superspecies complex Mus musculus sensu lato) from the Transcaucasian region: a new look at dispersal routes and evolution. Genetika 40, 1234-1250 (2004).

72. Anthony, D. W. \& Chi, J. The lost world of old Europe: the Danube Valley, 5000-3500 BC. (Princeton University Press (2010).

73. Van Neer, W., Linseele, V., Friedman, R. \& De Cupere, B. More evidence for cat taming at the Predynastic elite cemetery of Hierakonpolis (Upper Egypt). Journal of Archaeological Science 45, 103-111 (2014).

74. Held, S. O. Colonization cycles in Cyprus. 1: The biogeographic and palaeontological foundation of early prehistoric settlements. 1-28 (1989).

75. Vigne, J.-D. et al. First wave of cultivators spread to Cyprus at least 10,600 y ago. PNAS 109, 8445-8449 (2012).

76. Davis, S. J., Lernau, O. \& Pichon, J. The animal remains: New light on the origin of animal husbandry. In Le site de Hatoula en Judée occidentale, Israël (Association Paléorient, 1994).

77. Gourichon, L. \& Helmer, D. Etude archéozoologique de Mureybet. In Tell Mureybet, un site néolithique dans le Moyen Euphrate syrien 115-227 (Archeopress, 2008).

78. Grosman, L. et al. Nahal Ein Gev II, a Late Natufian community at the Sea of Galilee. Plos one 11, e0146647 (2016).

79. Bridault, A., Rabinovich, R. \& Simmons, T. Human activities, site location and taphonomic process: a relevant combination for understanding the fauna of Eynan (Ain Mallaha), level Ib (final Natufian, Israel). MOM Éditions 49, 99-117 (2008).

80. Edwards, Y. H. \& Martin, L. Fauna from the Natufian and PPNA Cave Site of Iraq ed-Dubb in Highland Jordan. Paléorient 33, 143-174 (2007).

81. Baca, M. et al. Human-mediated dispersal of cats in the Neolithic Central Europe. Heredity (Edinb), https://doi.org/10.1038/ s41437-018-0071-4 (2018)

82. Becker, C. Kastanas: Ausgrabungen in einem Siedlungshügel der Bronze-und Eisenzeit Makedoniens 1975-1979. Die Tierknochenfunde. vol. 4 (Volker Spiess, 1986).

83. Vigne, J.-D. Cat: domestication. Encyclopedia of Global Archaeology 1175-1177 (2014).

84. Papayannis, K. The micromammals of Minoan Crete: Human intervention in the ecosystem of the island. in Proceedings of the 9th European Vertebrate Palaeontology Association Meeting, Herakleion 2011, (eds. Iliopoulos, G., Meyer, C., Frey, E., Buffetaut, E., Liston, J., Osi, A.) vol. 92 239-248 (2012).

85. Payne, S. Appendix 5.1: The small mammals. in The Kommos region and the houses of the Minoan town. Part 1: the Kommos region, ecology and Minoan industries (eds. Shaw, J.W. and Shaw, M.) 278-291 (Princeton University Press, 1995).

86. Detournay, B., Poursat, J. P. \& Vandenabeele, F. Fouilles exécutées à Malia: le quartier Mu. II, Vases de pierre et de métal, vannerie, figurines et reliefs d'applique, éléments de parure et de décoration, armes, sceaux et empreintes. (Écoles Française d’Athènes, 1980). 
87. Pomadère, M. \& Papayianni, K. The cat, an exotic animal in the Minoan world? in John Younger Festschrift, Aegeum (B.Davis and R. Laffineur, in press).

88. Rohlf, F. J. tpsDig2. (Department of Ecology and Evolution, State University of New York at Stony Brook, 2017).

89. Gerasimov, S., Nikolov, H., Mihailova, V., Auffray, J. C. \& Bonhomme, F. Morphometric stepwise discriminant analysis of the five genetically determined European taxa of the genus Mus. Biological Journal of the Linnean Society 41, 47-64 (1990).

90. Mitteroecker, P. \& Bookstein, F. Linear discrimination, ordination, and the visualization of selection gradients in modern morphometrics. Evolutionary Biology 38, 100-114 (2011).

91. Kuhl, F. P. \& Giardina, C. R. Elliptic Fourier features of a closed contour. Computer graphics and image processing 18, 236-258 (1982).

92. Corny, J. \& Détroit, F. Technical Note: Anatomic identification of isolated modern human molars: Testing procrustes aligned outlines as a standardization procedure for elliptic fourier analysis. American Journal of Physical Anthropology 153, 314-322 (2014).

93. Sheets, H. D., Covino, K. M., Panasiewicz, J. M. \& Morris, S. R. Comparison of geometric morphometric outline methods in the discrimination of age-related differences in feather shape. Frontiers in Zoology 3, 15 (2006).

94. Fraley, C. \& Raftery, A. E. MCLUST version 3: an R package for normal mixture modeling and model-based clustering. (2006).

95. Ripley, B. D. Modern applied statistics with S. Statistics and Computing (fourth ed.) New York (Springer, 2002).

96. Ripley, B. D. Pattern recognition and neural networks. (Cambridge university press, 2007).

97. Suzuki, H. et al. Evolutionary and dispersal history of Eurasian house mice Mus musculus clarified by more extensive geographic sampling of mitochondrial DNA. Heredity (Edinb) 111, 375-390 (2013).

98. Suzuki, H., Yakimenko, L. V., Usuda, D. \& Frisman, L. V. Tracing the eastward dispersal of the house mouse, Mus musculus. Genes and Environment 37, 20 (2015).

99. Binladen, J., Gilbert, M. T. P., Campos, P. F. \& Willerslev, E. 5'-tailed sequencing primers improve sequencing quality of PCR products. BioTechniques 42(174), 176 (2007).

100. Cersoy, S., Zazzo, A., Lebon, M., Rofes, J. \& Zirah, S. Collagen Extraction and Stable Isotope Analysis of Small Vertebrate Bones: A Comparative Approach. Radiocarbon 59, 679-694 (2017).

101. Wacker, L., Němec, M. \& Bourquin, J. A revolutionary graphitisation system: Fully automated, compact and simple. Nuclear Instruments and Methods in Physics Research Section B: Beam Interactions with Materials and Atoms 268, 931-934 (2010).

102. Ruff, M. et al. On-line Radiocarbon Measurements of Small Samples Using Elemental Analyzer and MICADAS Gas Ion Source. Radiocarbon 52, 1645-1656 (2010).

103. Wacker, L. et al. A versatile gas interface for routine radiocarbon analysis with a gas ion source. Nuclear Instruments and Methods in Physics Research Section B: Beam Interactions with Materials and Atoms 294, 315-319 (2013).

104. Wacker, L. et al. MICADAS: Routine and High-Precision Radiocarbon Dating. Radiocarbon 52, 252-262 (2010).

105. Wacker, L., Christl, M. \& Synal, H.-A. Bats: A new tool for AMS data reduction. Nuclear Instruments and Methods in Physics Research Section B: Beam Interactions with Materials and Atoms 268, 976-979 (2010).

106. Scott, E. M., Cook, G. T. \& Naysmith, P. A Report on Phase 2 of the Fifth International Radiocarbon Intercomparison (VIRI). Radiocarbon 52, 846-858 (2010).

107. Bronk-Ramsey, C. Bayesian Analysis of Radiocarbon Dates. Radiocarbon 51, 337-360 (2009).

108. Bronk-Ramsey, C. \& Lee, S. Recent and Planned Developments of the Program OxCal. Radiocarbon 55, 720-730 (2013).

109. van Klinken, G. J. Bone Collagen Quality Indicators for Palaeodietary and Radiocarbon Measurements. Journal of Archaeological Science 26, 687-695 (1999).

\section{Acknowledgements}

K.P. was funded by a grant from Agence Nationale de la Recherche under the LabEx ANR-10-LABX-0003-BCDiv, in the program "Investissements d'avenir" ANR-11-IDEX-0004-02, and by the Malcolm H. Wiener Laboratory (ASCSA, Athens). We would like to thank the directors of the various excavations in Greece for providing access to the material analyzed in this paper as well as contextual info: G. Karamitrou-Mentessidi (Mavropigi and Xirolimni), G. Stratouli (Avgi and Drakaina), N. Kyparissi-Apostolika (Theopetra and Koutroulou-Magoula), Z. Tsirtsoni (Dikili Tash), A. Papathanasiou (Alepotrypa), A. Sampson (Sarakenos), C. Doumas (Akrotiri), M. Vlasaki (Chania and GSE), E. Hallager (GSE), J. Soles and C. Davaras (Mochlos), M. Pomadere (Malia), as well as the archaeologists, archaeobotanists and excavation staff that made the soil flotation and retrieved the mouse bones. Analysis permits for the bones from Greek sites were issued by the Hellenic Ministry of Culture and Sports. Analysis permit for the Çatalhöyük site was issued by the Ministry of Culture and Tourism of the Republic of Turkey. S C was funded by State Aid, managed by the French National Research Agency (ANR), namely LabEx ANR-10-LABX-0003-BCDiv, within the framework of the "Investissements d'avenir" program number ANR-11-IDEX-0004-02, and by the MNHN funding program, "Action Thématiques du Muséum". The authors would like to thank the Région Ile de France (DIM Analytics), the Fond européen de développement régional (FEDER), the Fondation BNP Paribas, the Labex BCDiv, the LSCE (CEA, CNRS, Univ. Versailles SaintQuentin), GEOPS (CNRS, Univ. Paris Sud) and the AASPE (MNHN, CNRS) for their contribution to the funding of ECHoMICADAS. We are also very grateful to C. Gauthier, E. Kaltnecker, F. Thil and N. Tisnerat-Laborde, from the EchoMICADAS team, for the radiocarbon dates (graphitization, AMS measurements and data reduction). MM, FB, SM AND LW, thank CHHTO (Ministry of Cultural Heritage, Tourism and Handicrafts), The National Museum of Iran, and the University of Tehran for their support of archaeological excavations and for giving access to the archaeological material from Iran. Bertille Lyonnet and the late Olivier Lecomte authorized the study of the material from Chishkho (Adygea Republic) and Ulug Depe (Turkmenistan). The mice teeth from Elazıg and Norşuntepe were photographed by RB in 2012 in the Mammalogy Department of the Senckenberg Naturmuseum Frankfurt with the kind permission of Dr. Ottmar Kullmer and the help of Dr. Virginie Volpato, Dr. Thomas Lehmann and Ms. Katryn Krohmann. We are most grateful to Professor C. Pulak (Texas A\&M University) for giving us access to the mouse mandible from the Uluburun Project. Many thanks to the Çatalhöyük project for allowing analysis of the mouse samples, to S. Davis (Laboratorio de Arqueociencias, Portugal) and D. Helmer for giving us access to the material of Khirokitia and Cap Andreas in Cyprus. For access to small mammal material from Vinča - Belo Brdo, and associated documentation, we thank D. Filipović, K. Penezić, J. Bulatović, and N. Tasić. Initial identifications of the Vinča - Belo Brdo small mammal fauna were carried out by K. Locker. Many thanks to Didier G. Kuriyama for providing us free use of the map he created and that we modified to create the Figure 1. Many thanks to Jill Cucchi for copy-editing and to Julien Corny for his help on the R scripts for Elliptic Fourier Analysis. 


\section{Author contributions}

T.C. designed the research study. K.P., T.C. and R.B. collected the images of teeth for G.M.M. analyses. K.P. performed the G.M.M. data acquisition. T.C. and K.P. analysed and interpreted the G.M.M. data. K.P. and T.C. collected the archaeological samples for aDNA and radiocarbon dating. Palaeogenetic analyses have been performed by L.A.C. and R.D. Radiocarbon dating have been performed by S.C. and A.Z. R.B., A.B., A.S., F.V., Y.H., F.M., M.M., J.D., R.S., F.B., C.A.P., L.W., A.S.Z., S.M., D.O., E.J. have provided archaeological samples of Mus sp. for G.M.M. analysis and details and dates of the archaeological contexts from which they were recovered. T.C. and K.P. have written the manuscript with the scientific and editing input from J.D.V., J.C.A., F.B., J.B.S., G.L., D.O., M.Z., C.D., Y.H. and M.M. All authors reviewed the manuscript and the supplementary information.

\section{Competing interests}

The authors declare no competing interests.

\section{Additional information}

Supplementary information is available for this paper at https://doi.org/10.1038/s41598-020-64939-9.

Correspondence and requests for materials should be addressed to T.C.

Reprints and permissions information is available at www.nature.com/reprints.

Publisher's note Springer Nature remains neutral with regard to jurisdictional claims in published maps and institutional affiliations.

(c) (i) Open Access This article is licensed under a Creative Commons Attribution 4.0 International License, which permits use, sharing, adaptation, distribution and reproduction in any medium or format, as long as you give appropriate credit to the original author(s) and the source, provide a link to the Creative Commons license, and indicate if changes were made. The images or other third party material in this article are included in the article's Creative Commons license, unless indicated otherwise in a credit line to the material. If material is not included in the article's Creative Commons license and your intended use is not permitted by statutory regulation or exceeds the permitted use, you will need to obtain permission directly from the copyright holder. To view a copy of this license, visit http://creativecommons.org/licenses/by/4.0/.

(c) The Author(s) 2020 